\title{
A Review of Biodegradation as a Panacea for Palm Oil Mill Effluents (POME) Pollution
}

\author{
Grace M. Adegbola ${ }^{1}$, Adekunle O. Adeoye ${ }^{1}$ and Simeon K. Olatunde 2* $^{*}$ \\ ${ }^{1}$ Department of Food science and Engineering Technology, Ladoke Akintola University of \\ Technology, Ogbomoso, Oyo state, Nigeria \\ ${ }^{2}$ Department of Pure and Applied Biology, Ladoke Akintola University of Technology, \\ Ogbomoso, Oyo state, Nigeria \\ *Corresponding author
}

\section{A B S T R A C T}

\section{Keywords}

Biodegradation, Environmental, Microorganisms, Palm Oil Mill Effluent, Pollution

\section{Article Info}

Accepted:

17 October 2020 Available Online: 10 November 2020
The wastewater generated from sterilization, condensation and hydrocycloning of palm oil fruits during milling activities is referred to as Palm oil mill effluent (POME). It shows the presence of residue oil and suspended solids, due to its high biological oxygen demand (BOD), low $\mathrm{pH}$ and colloidal nature, its potentials to pollute both ecological niches have been attributed to the most intricate environmental turmoil for the 21 st century. Currently, the penetration of palm oil mill effluents into the waterways and ecosystems has been considered a meticulous concern towards the food chain interference and water consumption. However, by the virtue of both anaerobic and aerobic biological treatment, some variety of microorganisms have been investigated to be capable of POME biodegradation, with the sole aim of providing a solution to environmental pollution problems, this is rapidly growing in recent decades where POME hydrocarbons and its derivatives are concerned. Organisms that have been successfully reported to be capable of degrading these hydrocarbons include Pseudomonas aeruginosa, Bacillus subtilis, Alcaligenes, Acinetobacter iwoffi, Flavobacterium sp., Aspergillus sp., and Rhizopus. Therefore, this article presents a characteristic review of POME pollution with new and emerging biodegradation potentials as a panacea to global issues plaguing our ecological niches, major limitations together with the future expectation are summarized and discussed.

\section{Introduction}

Palm oil mill effluent (POME) which is also known as Palm oil effluent (POE), Palm oil slurry (POS) or Palm oil sludge (POS) is a perennial crop with the most common species "Elaeis guineensis" grown extensively in West Africa's humid tropical and subtropical region, where it originated from (Bambang et al., 2012; Alam et al., 2007), however the world's largest producers of crude palm oil are actually Indonesia, Malaysia, Thailand, Columbia and Nigeria (Ohimain and Izah, 2014; Izah et al., 2016). Among all territorial name been given, Palm oil mill effluent seems to summarize it's content which is defined as 
the voluminous liquid waste that originates from the sterilization and clarification forms in milling oil palm. It is a wastewater produced from palm oil milling exercises which require successful treatment before release into nature because of its exceptionally polluting properties (Wu et al., 2009; Ismail et al., 2010). Thus, POME is being treated via palm oil mills before evacuating it into the streams and rivers. Figure 1 presents the schematic process of Palm fruits processing to product (Oil) and effluent waste. Palm oil mill effluent is termed to be a highly polluting material and researchers have done so much in their studies to find ways of removing its threat to the environment (Awotoye et al., 2011; Izah and Ohimain, 2016). The composition of the effluents are from different sources and are obtained from palm oil, water, sand and solid (suspended and dissolved). Water which composed of 93-95\%, solidly composed of 3$4 \%$ and oil composed of $0.5-2 \%$ are various composition as a percentage of total sludge (Madaki et al., 2013).

Biodegradation also known as "biological breakdown" is the process by which organic substances are decomposed by microorganisms (mainly aerobic bacteria) into simpler substances such as carbon dioxide, water and ammonia. The use of biotechnological forms including microorganisms, with the target of taking care of environmental contamination issues, is quickly developing where POME and its sideeffects are concerned (Pala et al., 2006). The process by which microorganisms such as bacteria, fungi and other biological activity act on material by naturally disintegration is called Biodegradation. The biological treatment relies immensely upon a consortium of microorganism's activities, which operate the organic substances present in the POME as enhancements and in the end debase these organic issues into a simple by-product, for example, methane, carbon dioxide and hydrogen provided, and water (Mohammadreza and Soheila, 2014).

According to Liew et al., (2015), the past few decades, various methods have been recorded for the treatment of POME. Anaerobic or facultative ponding method, tank digestion and mechanical aeration, tank digestion and facultative ponds, physico-chemical and biological care, and decanter and facultative ponds are the most refined treatment plans that have been widely applied in POME degradation. However, these approaches have some disadvantages, such as the prolonged period of retention, greenhouse gases output, large land area requirement and inconsistent nutrient removal (Ganapathy et al., 2019; Affandi et al., 2014). Biological treatment such as ponding system is a conventional treatment that involves aerobic and anaerobic processes which involves microorganisms such as bacteria, molds, algae, yeasts, and fungi to degrade lipids in the POME (Ganapathy et al., 2019; Rupani, et al., 2019; Chan et al., 2005).

One of the unique ways through which microorganisms obtains energy is by catalyzing energy that causes chemical reactions involving breaking bonds and moving electrons away from the pollutants, during this process, the organic contaminant is oxidized in this form of reaction, while the chemical that acquires the electron is reduced. The energy obtained from this transition is then invested in growth and metabolism of the biodegrading microbe. Aerobic species utilized oxygen as their electron acceptor, while anaerobes use nitrates, sulphates, or even carbon dioxide as their own electron acceptor, and products produced here can include nitrogen gas, hydrogen sulphide, decreased metal types, and methane, depending on the electron acceptor which is in addition to new cell mass. This mechanism 
has been used to biodegrade several POME polluted sites (Ramadan et al., 2012; Loretta et al., 2016).

This article presents a narrative review of POME pollution with new and emerging biodegradation potentials as a panacea to global issues plaguing our ecological niches, advantages and major limitations together with the future expectation are summarized and discussed.

\section{Biological agent involved in Biodegradation of POME}

A variety of microorganisms have been investigated to be capable of biodegrading oil wastewater with high profits. The microorganisms that can perform complete degradation of oil-based waste water are bacteria, moulds, yeasts, and fungus (Dhouib et al., 2006). The use of microorganisms for biodegradation purposes is also an extremely efficient method for the treatment of highly polluted waste water and natural bodies of water. Anaerobic and aerobic treatments are the great and capable biological methods for POME treatment (Nwuche, Aoyagi, and Ogbonna, 2014).Organisms that have been successfully reported to be capable of degrading these hydrocarbons include Pseudomonas aeruginosa, Bacillus subtilis, Alcaligenes, Acinetobacter iwoffi, Flavobacterium sp., Aspergillus sp., and Rhizopus (Loretta et al., 2016). Affandi et al, (2014) demonstrated that through aerobic treatment, an indigenously isolated Bacillus cereus has the ability to extract oil and grease from POME absolutely. It was reported by Vijayaraghavan et al., (2007) that in anaerobically digested POME, the chemical demand for oxygen (COD) and oil and grease removal by aerobic oxidation was higher. One of the very first researchers to reports aerobic digestion of POME are Agamuthu et al., (1986), they observed a significant decrease in carbon and inorganic nitrogen content which eventually changes the $\mathrm{pH}$ of POME from acidic to alkaline range.

Furthermore, Fungal and yeast species such as Saccharomyces cerevisiae, Yarrowia lipolytica, spores and mycelium of Trichoderma viride, Aspergillus fumigatus and Coilostylis clavate have been effectively applied in the treatment of POME in recent studies (Neoh et al., 2013; Oswal et al., 2002). Aspergillus niger and Aspergillus flavus have been distinguished for their ability to endure oily wastewater such as POME, this explain their ability to breakdown chemical component found in pome and utilizes as their sole carbon source. The presence of Penicillium sp., Fusarium sp., and Mucor sp. in the POME shows that these fungi are able to survive in hostile environment (Ohimain et al., 2012a; Ohimain et al., 2012b; Nwuche and Ogbonna, 2011). These organisms have been proven in recent report to be an effective oily wastewater degrader.

\section{The characteristics properties of POME}

The characteristics properties of POME vary and differs from each other depending on the processing techniques, life span and specie of palm fruits, and the palm oil mill activities (Ravindra and Sarbatly, 2013; Wu et al., 2010). It is considered to be one of the recalcitrant wastes containing elevated amounts of organic compounds with a very high Biochemical Oxygen Demand (BOD) and Chemical Oxygen Demand (COD), which is 100 times more than the municipal sewage (Wu et al., 2010: Khongkhaem et al., 2016). A standard palm oil mill produces approximately one ton of liquid waste with a biochemical demand for oxygen (BOD) of 27 $\mathrm{kg}$, a chemical demand for oxygen (COD) of $62 \mathrm{~kg}$, suspended solids (SS) of $35 \mathrm{~kg}$ and oil and grease of $6 \mathrm{~kg}$ (Kamyab et al., 2018).POME is a non-toxic waste, since no 
solvent is applied during the oil extraction process, but due to the organic and nutrient content, it has the ability to pose serious environmental problems because of its high oxygen depleting potential in the aquatic system (Khongkhaem et al., 2016).

Figure 2 shows a schematic flow of different stages involved in biological treatment of palm oil mill effluent (POME) within a typical palm oil mill, comprising of anaerobic, aerobic and facultative anaerobic processes, including mixed raw effluent (MRE), mixing pond, holding tank, and final discharge phases. The suspended solids in the POME are mainly oil-bearing cellulosic materials from the fruits. Since the POME is non-toxic as no chemical is added in the oil extraction process, it is a good source of nutrients for microorganisms. POME constituent includes carbohydrates, proteins and large quantities of fatty acids and oil. Various phenolic and heterocyclic compounds from palm fruits are also released to POME (Unell et al., 2008; Aresta et al., 2010; Khongkhaem et al., 2016).

\section{Ponding system as the conventional method}

Biological treatment such as ponding system is a conventional treatment method involving aerobic and anaerobic processes with microorganisms such as bacteria, molds, algae, yeasts, and fungi to degrade lipids in the POME (Chan et al., 2010). The most common method adopted by more than 85 percent of palm oil mills is the ponding system. Ponding usually entails lagoons (ponds) and oxidation artificial pools for waste stabilization. However, oxidation ponds can be categorized as aerobic, likewise facultative ponds when oxygen is absent, sand and oil traps, cooling ponds, acidification ponds, anaerobic ponds are usually included in the ponding scheme. Sand and oil traps run manually are pretreatment unit operations, the raw POME is cooled down to less than $35^{\circ} \mathrm{C}$ in cooling ponds prior to feeding into subsequent ponds (Yacob et al., 2006a; Chan et al., 2010; Liew et al., 2015)

Aerobic ponds are normally built up to 1-1.5 $\mathrm{m}$ deep, while anaerobic ponds are normally 5-7 $\mathrm{m}$ deep, without lining, all within the earth structure, organic loading ranges may rate from 0.2 to $0.35 \mathrm{~kg} \mathrm{BOD} \mathrm{m}^{-3}$ per day1. It is worthy to know that anaerobic ponding can digest large amounts of solids and is inexpensive, but requires long retention times and a wide land area with regularly recorded accumulation of solids (Hojjat et al., 2009). The ponding system entails low maintenance, it is economical, it offers process and operational simplicity, and is a feasible means of treating high strength organic wastewater (Yacob et al., 2006b; Yacob et al., 2006a; Liew et al., 2015).

\section{Advancement in POME treatment}

The quality needed to reduce the contaminants in the POME to acceptable levels is not achieved by various conventional treatment approaches. However, to lower the levels of pollutants, many advanced treatment technologies have been developed with high efficiency. A feasible tactic for POME treatment includes the integration of both conventional treatment and advanced technologies. Advanced treatment entails chemical and physical treatments of POME. Chemical treatment act by changing the chemical properties, such as acid neutralization or alkalinity. Meanwhile, before any secondary treatment, physical procedures include screening, sedimentation, and oil removal are also important for effective biological degradation of POME (Yashni, et al., 2020). 
Fig.1 From fruits processing to product (Oil) and effluent waste



Fig.2 Schematic flow process for both Anaerobic and Facultative biodegradation of Palm oil mil effluents (POME)

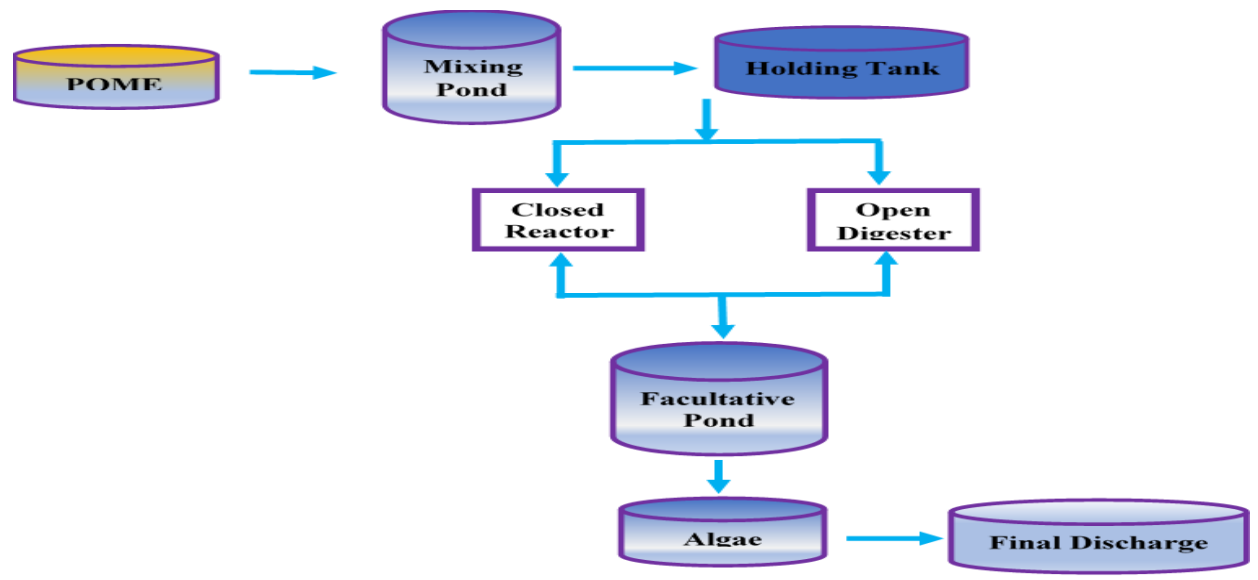

Photocatalysis is an advanced oxidation process (AOP) that provides the treatment of POME with a promising green approach (Yashni et al., 2020). A catalyst or semiconductor such as titanium dioxide $(\mathrm{TiO} 2)$ and zinc oxide $(\mathrm{ZnO})$ are used to effectively convert POME contaminants into harmless products through the production of sufficient quantities of hydroxyl radicals $(\mathrm{OH})$. By utilizing photon energy from solar light illumination, photocatalysis decomposes organic pollutants (Chin et al., 2019; Cheng et al., 2017). Another treatment method for advanced oxidation process (AOP) of POME is Fenton oxidation, this protocol is widely explored for POME treatment due to its ease of operation and potential to degrade harmful substances to form intermediates with enhanced biodegradability (Yashni et al., 2020). Fenton oxidation process utilizes Fenton reagents such as hydrogen peroxide $(\mathrm{H} 2 \mathrm{O} 2)$ and ferrous ion $(\mathrm{Fe} 2 \mathrm{p})$ in the presence of light to produce $(\mathrm{OH})$ and oxidation of $\mathrm{Fe} 2 \mathrm{p}$ to ferric ions $(\mathrm{Fe} 3 \mathrm{p})$ which trigger the degradation of organic compounds. The techniques appear to works faster and require less energy and space which makes it a costeffective technology (Kanakaraju et al., 2017; Gamaralalage et al., 2019) 
Sia et al., (2017) defined Electro-oxidation as an effectual method for pollutant degradation by using electrochemically produced oxidants to perform direct and indirect oxidation. This technique utilizes electrical potential where the cathode surface is coated with ionized metallic species. This method requires less chemicals and creates less sludge, but the high initial cost of capital and the expensive source of electricity limit its effectiveness (Ahmad et al., 2019). Coagulationflocculation is an innovative pretreatment procedure for waste water treatment. The method is combined with other methods for treatment, such as biological treatment, filtration of the membrane and AOPs (Ohimain and Izah, 2014a). A process of gathering colloidal particles into large masses is coagulation. Colloidal particle collection occurs by two distinct mechanisms such as movement of particle to effect interparticle contact and Dislocation of particles to allow attachment as contact ensues (Ohimain and Izah, 2014b).

Electrocoagulation is an efficient traditional process for the recovery of useful chemical substances and for the disposal of waste water, such as POME (Bashir et al., 2016). Electrocoagulation is a method in which electrode metal creates metal ions that are then hydrolyzed in the electrochemical cell to create metal hydroxide that binds to disrupted contaminants with great adsorptive properties and thus produces large flocks (Yashni et al., 2020). Ultrafiltration is often preferred for effluent treatment between many membrane processing practices. Ultrafiltration is a membrane process powered by low pressure, where some solution components are isolated from the solvent, leaving only the macromolecules within 0.001-0.02 mm (Ohimain and Izah, 2017).

Ultrasonication is the irradiation from ultrasound with frequency in the range of 15-
$20 \mathrm{kHz}$. It is recognized as green technology for numerous wastewater treatments with higher decomposition rates compared to traditional methods (Wong, Isa and Bashir, 2018). Ultrasonication degrades complex organic contaminants in the wastewater by the development and breakdown of high energy cavitation bubbles. Ultrasound irradiation is characterized with a frequency in the range of $15-20 \mathrm{kHz}$. For common effluent treatments with higher decomposition rates compared to conventional approaches, it is recognized as green technology, ultrasonics degrade complex organic pollutants in waste water (Yashni et al., 2020). Adsorption is a physicochemical mechanism in which the contaminants are adsorbed as a result of physical forces or chemical reactions on the surface of the adsorbents. A promising technique for removing heavy metals, organic contaminants, residual oil, and Suspended solid from POME is adsorption (Parthasarathy et al., 2015; Azmi andYunos, 2016; Ng et al., 2019).

\section{Major limitations and future prospects}

The major limitations of the biological treatment methods such as aerobic and anaerobic treatment include high retention time, low removal efficiency for some parameters such as Total Nitrogen, Total suspended Solid, and Total Dissolve Solid (Yashni et al., 2020). The requirement of large land area and proper monitoring as the processes rely on microorganisms to break down the pollutants has also been reported to be a limiting factor. The disadvantages of these advanced treatments methods include generation of hazardous sludge, high dosages of chemicals, high cost, high requirement for electricity, as well as the formation of oxide or passive film on the surface of the electrodes, which reduce the efficiency of the process (Abdurahman et al., 2013; Abdelgadir et al., 2014; Ohimain and Izah, 2017). 
According to Yashni et al., (2020), current studies reveal that, the palm oil industries have shown interest in incorporating more sustainable and emerging technologies in their mills to achieve a zero-waste solution, including biogas extraction and/or composting technology. Besides biogas trapping and composting technology, another groundbreaking concept of combining oil oil extraction and continuous filtration by super hydrophobic membrane has been anticipated recently to achieve zero-sludge palm oil mill (Zainal et al., 2018). Liew et al., (2015) opine that there are still ongoing treatment technologies being researched and the outcomes maybe available in a while. However, the most feasible technology could be the combination of advanced biological processes (bioreactor systems) with extended aeration, followed by solids separation prior to discharge ( $\mathrm{Ng}$ et al., 2011).

In conclusion the more problems are expected as the oil palm industry continues to move into a new age, discharging the effluents or by-products on the lands may lead to pollution and might cause deterioration of the environment. The treatment of these byproducts requires a productive and efficient management system that will preserve the environment and check the deterioration of run water and air quality. Treatment of POME is highly important and environmental pollution must be avoided. Among several convectional treatment of POME, "Biodegradation" which is the biological treatment of POME with some varieties of microorganism appears to be a panacea for Ecological pollution. In other to lower the levels of pollutants, many advanced treatment technologies have been developed with high efficiency. A feasible tactic for POME treatment includes the integration of both conventional treatment and advanced technologies. Therefore, as the industry progress vigorously over the years, many factors should be investigated in order to get further insights of POME management. The emergence of hybrid palm fruits and many other new varieties, the development of milling processes as a result of technical developments, as well as the water supplies used in palm oil mills may be an indicator of new evidence of discovery and innovation for a breakthrough in the research of palm oil waste water.

\section{References}

Abdelgadir, A., Chen, X., Liu, J., Xie, X., Zhang, J., Zhang, K., and Liu, N. (2014). Characteristics, process parameters, and inner components of anaerobic bioreactors. BioMed Research International.

Abdurahman, N. H., Rosli, Y. M., and Azhari, N. H. (2013). The performance evaluation of anaerobic methods for Palm Oil Mill Effluent (POME) treatment: A review. International perspectives on water quality management and pollutant control, 88106.

Affandi, I. E., Suratman, N. H., Abdullah, S., Ahmad, W. A., and Zakaria, Z. A. (2014). Degradation of oil and grease from high-strength industrial effluents using locally isolated aerobic biosurfactant-producing bacteria. International Biodeterioration and Biodegradation, 95, 33-40.

Agamuthu, P., Tan, E. L., and Shaiful, A. A. A. (1986). Effect of aeration and soil inoculum on the composition of palm oil mill effluent (POME). Agricultural Wastes, 15(2), 121-132.

Ahmad, A. L., Sumathi, S., and Hameed, B. H. (2005). Adsorption of residue oil from palm oil mill effluent using powder and flake chitosan: equilibrium and kinetic studies. Water research, 39(12), 2483-2494. 
Ahmad, A., Bhat, A. H., Buang, A., Shah, S. M. U., and Afzal, M. (2019). Biotechnological application of microalgae for integrated palm oil mill effluent (POME) remediation: a review. International Journal of Environmental Science and Technology, 16(3), 1763-1788.

Alam, M. Z., Kabbashi, N. A., and Razak, A. A. (2007). Liquid state bioconversion of domestic wastewater sludge for bioethanol production. In $3 r d$ Kuala Lumpur International Conference on Biomedical Engineering 2006 (pp. 479-482). Springer, Berlin, Heidelberg.

Aresta, M., Acquaviva, M. I., Baruzzi, F., Noce, R. L., Matarante, A., Narracci, M.,. .. and Cavallo, R. A. (2010). Isolation and characterization of polyphenols-degrading bacteria from olive-mill wastewaters polluted soil. World Journal of Microbiology and Biotechnology, 26(4), 639-647

Awotoye, O.O., Dada, A.C., and Arawomo, G.A.O. (2011) Impact of palm oil processing effluent discharging on the quality of receiving soils and rivers in south Western Nigeria. Jurnal of Applied Sciences Research 7: 111-118.

Azmi, N. S., and Yunos, K. F. M. (2014) Wastewater Treatment of Palm Oil Mill Effluent (POME) by Ultrafiltration Membrane Separation Technique Coupled with Adsorption Treatment as Pre-Treatment. Agric. Agric. Sci. Proc., 2, 257-264. DOI: 10.1016/j.aaspro.2014.

Bambang, T., Vivian, W., and Yoshimasa, T. (2012). Methane emission from digestion of palm oil mill effluent (POME) in a thermophilic anaerobic reactor. International Journal of Science and Engineering, 3(1), 32-35.

Bashir, M. J. K., Mau Han, T., Jun Wei, L., ChoonAun, N., and Abu Amr, S. S.
(2016) Polishing of Treated Palm Oil Mill Effluent (POME) from Ponding System by Electrocoagulation Process. Water Sci. Technol. 2016, 73, 27042712. DOI: $10.2166 /$ wst..123.

Chan, Y. J., Chong, M. F., and Law, C. L. (2011). Optimization on thermophilic aerobic treatment of anaerobically digested palm oil mill effluent (POME). Biochemical engineering journal, 55(3), 193-198.

Chan, Y.J., Chong, M.F., Law, C.L., (2010). Biological treatment of anaerobically digested palm oil mill effluent (POME) using a lab-scale sequencing batch reactor (SBR). J. Environ. Manag. 9, 1738e1746.

Cheng, Y. W., Chang, Y. S., Ng, K. H., and Wu, T. Y.; Cheng, C. K. Photocatalytic Restoration of Liquid Effluent from Oil Palm Agroindustry in Malaysia Using Tungsten Oxides Catalyst. J. Clean. Prod., 162, 205-219.

Chin, Y. H., Sin, J. C., Lam, S. M., and Mohamed, A. R. (2019). Preparation of $\mathrm{Nb} 2 \mathrm{O}$ 5-decorated hierarchical porous $\mathrm{ZnO}$ microspheres with enhanced photocatalytic degradation of palm oil mill effluent. Journal of Materials Science: Materials in Electronics, 30(2), 1739-1750.

Dhouib, A., Ellouz, M., Aloui, F., and Sayadi, S. (2006). Effect of bioaugmentation of activated sludge with white-rot fungi on olive mill wastewater detoxification. Letters in Applied Microbiology, 42(4), 405-411.

Gamaralalage, D., Sawai, O., and Nunoura, T. (2019) Degradation Behavior of Palm Oil Mill Effluent in Fenton Oxidation. J. Hazard. Mater, 364, 791-799.

Ganapathy, B., Yahya, A., and Ibrahim, N. (2019). Bioremediation of palm oil mill effluent (POME) using indigenous Meyerozyma guilliermondii. Environmental Science and Pollution 
Research. doi:10.1007/s11356-01904334-8

Hojjat, M., and Salleh, M. A. M. (2009). Optimization of POME anaerobic pond. Eur. J. Sci. Res, 32(4), 45.

Ismail, I., Hassan, M. A., Rahman, N. A. A., and Soon, C. S. (2010). Thermophilic biohydrogen production from palm oil mill effluent (POME) using suspended mixed culture. Biomass and Bioenergy, 34(1), 42-47.

Izah, S. C., Angaye, T. C., and Ohimain, E. I. (2016). Environmental Impacts of Oil palm processing in Nigeria. Biotechnological Research, 2(3), 132141.

Izah, S.C. and Ohimain, E.I. (2016). Microbiological quality of palm oil used in Nigeria: Health impacts perspective. Point Journal of Botany and Microbiology Research, 2(1): 037 -045 .

Environmental Impacts of Oil Palm Processing in Nigeria (PDF).

Kamyab, H., Chelliapan, S., Din, M. F. M., Rezania, S., Khademi, T., and Kumar, A. (2018). Palm oil mill effluent as an environmental pollutant. Palm Oil, 13.

Kanakaraju, D., Ahmad, N. L. B., Sedik, N. B. M., Long, S. G. H., Guan, T. M., and Chin, L. Y. (2017). Performance of solar photocatalysis and photoFenton degradation of palm oil mill effluent. Malaysian Journal of Analytical Sciences, 21(5), 996-1007.

Khongkhaem, P., Suttinun, O., Intasiri, A., Pinyakong, O., and Luepromchai, E. (2016). Degradation of phenolic compounds in palm oil mill effluent by silica-immobilized bacteria in internal loop airlift bioreactors. CLEAN-Soil, Air, Water, 44(4), 383-392.

Liew, W. L., Kassim, M. A., Muda, K., Loh, S. K., and Affam, A. C. (2015). Conventional methods and emerging wastewater polishing technologies for palm oil mill effluent treatment: A review. Journal of Environmental Management, 149, 222-235.

Loretta, O. O., Stephen, E., Ezeata, A., and Usman, E. (2016). In vitro biodegradation of palm oil mill effluent (POME) by Bacillus subtilis, Pseudomonas aeruginosa and Aspergillus niger. $J$ Bioremediat Biodegrad, 7(361), 2.

Mohammadreza, S., and Soheila. M, (2014) "Enhancement of Biodegradation of Palm Oil Mill Effluents by Local Isolated Microorganisms", International Scholarly Research Notices, vol. 2014, Article ID 727049

Neoh, C. H., Yahya, A., Adnan, R., Majid, Z. A., and Ibrahim, Z. (2013). Optimization of decolorization of palm oil mill effluent (POME) by growing cultures of Aspergillus fumigatus using response surface methodology. Environmental Science and Pollution Research, 20(5), 2912-2923.

Ng, K. H., Yuan, L. S., Cheng, C. K. Chen, K., and Fang, C. $\mathrm{TiO} 2$ and $\mathrm{ZnO}$ Photocatalytic Treatment of Palm Oil Mill Effluent (POME) and Feasibility of Renewable Energy Generation: A 16 G. YASHNI ET AL., Short Review. J. Clean. Prod., 233, 209-225.

Nwuche, C. O., and Ogbonna, J. C. (2011). Isolation of lipase producing fungi from palm oil mill effluent (POME) dump sites at Nsukka. Brazilian Archives of Biology and Technology, 54(1), 113-116.

Nwuche, C. O., Aoyagi, H., and Ogbonna, J. C. (2014). Treatment of palm oil mill effluent by a microbial consortium developed from compost soils. International scholarly research notices, 2014.

Ohimain, E. I., and Izah, S. C. (2014). Possible contributions of palm oil mill effluents to greenhouse gas emissions 
in Nigeria. Current Journal of Applied Science and Technology, Pp. 47054720.

Ohimain, E. I., \&Izah, S. C. (2017). A review of biogas production from palm oil mill effluents using different configurations of bioreactors. Renewable and Sustainable Energy Reviews, 70, 242-253.

Ohimain, E. I., Daokoru-Olukole, C., Izah, S. C., Eke, R. A., and Okonkwo, A. C. (2012a). Microbiology of palm oil mill effluents. Journal of Microbiology and Biotechnology Research, 2(6), 852857.

Ohimain, E. I., Seiyaboh, E. I., Izah, S. C., Oghenegueke, V., \&Perewarebo, T. (2012b). Some selected physicochemical and heavy metal properties of palm oil mill effluents. Greener Journal of Physical Sciences, 2(4), 131-137.

Ohimain, E.I., \&Izah, S.C. (2014 a)Potential of biogas production from palm oil mills' effluent in Nigeria. Sky J Soil Sci Environ Manag; 3(5): 50-8.

Ohimain, E.I., and Izah, S.C. (2014b) Estimation of potential electrical energy and currency equivalent from un-tapped palm oil mill effluents in Nigeria. Int J Farming Allied Sci; 3(8): 855-62.

Oswal, N., Sarma, P. M., Zinjarde, S. S., and Pant, A. (2002). Palm oil mill effluent treatment by a tropical marine yeast. Bioresource technology, 85(1), 35-37.

Pala, D. M., de Carvalho, D. D., Pinto, J. C., \&Sant'Anna Jr, G. L. (2006). A suitable model to describe bioremediation of a petroleumcontaminated soil. International Biodeterioration and Biodegradation, 58(3-4), 254-260.

Parthasarathy, S., Mohammed, R. R., Fong, C. M., Gomes, R. L., and Manickam, S. (2016). A novel hybrid approach of activated carbon and ultrasound cavitation for the intensification of palm oil mill effluent (POME) polishing. Journal of Cleaner Production, 112, 1218-1226.

Ramadan, K. M., Azeiz, A. A., Hassanien, S. E., \&Eissa, H. F. (2012). Biodegradation of used lubricating and diesel oils by a new yeast strain Candida viswanathii KA-2011. African Journal of Biotechnology, 11(77), 14166-14174.

Ravindra, P., and Sarbatly, R. H. (Eds.). (2013). Advances in biofuels. Springer Science and Business Media.

Rupani, P. F., Alkarkhi, A. F., Shahadat, M., Embrandiri, A., El-Mesery, H. S., Wang, H., and Shao, W. (2019). BioOptimization of Chemical Parameters and Earthworm Biomass for Efficient Vermicomposting of Different Palm Oil Mill Waste Mixtures. International journal of environmental research and public health, 16(12), 2092.

Sia, Y. Y., Tan, I. A. W., and Abdullah, M. O. (2017). Adsorption of colour, TSS and COD from palm oil mill effluent (POME) using acid-washed coconut shell activated carbon: Kinetic and mechanism studies. In MATEC Web of Conferences (Vol. 87, p. 03010). EDP Sciences.

Unell, M., Nordin, K., Jernberg, C., Stenström, J., and Jansson, J. K. (2008). Degradation of mixtures of phenolic compounds by Arthrobacter chlorophenolicus A6. Biodegradation, 19(4), 495-505.

Vijayaraghavan, K., Ahmad, D., and Aziz, M. E. B. A. (2007). Aerobic treatment of palm oil mill effluent. Journal of environmental management, 82(1), 2431.

Wong, L. P., Isa, M. H., and Bashir, M. J. K. (2018) Disintegration of Palm Oil Mill Effluent Organic Solids by 
Ultrasonication: Optimization by Response Surface Methodology. Process Saf. Environ. Prot., 114, 123132. DOI: 10.1016/j.psep.2017. 12.012.

Wu, T. Y., Mohammad, A. W., Jahim, J. M., and Anuar, N. (2009). A holistic approach to managing palm oil mill effluent (POME): Biotechnological advances in the sustainable reuse of POME. Biotechnology Advances, 27(1), 40-52.

Wu, T. Y., Mohammad, A. W., Jahim, J. M., and Anuar, N. (2010). Pollution control technologies for the treatment of palm oil mill effluent (POME) through end-of-pipe processes. Journal of environmental management, 91(7), 1467-1490.

Yacob, S., Hassan, M.A., Shirai, Y., Wakisaka, M., Subash, S., (2006a). Baseline study of methane emission from anaerobic ponds of palm oil mill effluent treatment. Sci. Total Environ. 366 (1), 187e196.
Yacob, S., Shirai, Y., Hassan, M.A., Wakisaka, M., Subash, S., (2006b). Start-up operation of semi-commercial closed anaerobic digester for palm oil mill effluent treatment. Process Biochem. 41, 962e964.

Yahaya, S., Madaki., and Lau Seng. (2013). Pollution Control: How Feasible is Zero Discharge Concepts in Malaysia Palm Oil Mills. American Journal of Engineering Research, 2(10), 239-252

Yashni, G., Al-Gheethi, A., Radin Mohamed, R. M. S., Arifin, S. N. H., and Mohd Salleh, S. N. A. (2020). Conventional and advanced treatment technologies for palm oil mill effluents: a systematic literature review. Journal of Dispersion Science and Technology, $1-19$.

Zainal, N. H., Jalani, N. F., Mamat, R., \&Astimar, A. A. (2017). A review on the development of palm oil mill effluent (POME) final discharge polishing treatments. Journal of Oil Palm Research, 29(4), 528-540.

\section{How to cite this article:}

Grace M. Adegbola, Adekunle O. Adeoye and Simeon K. Olatunde. 2020. A Review of Biodegradation as a Panacea for Palm Oil Mill Effluents (POME) Pollution. Int.J.Curr.Microbiol.App.Sci. 9(11): 2506-2516. doi: https://doi.org/10.20546/ijcmas.2020.911.303 